\title{
Jurnal Pendidikan Fisika
}

https://journal.unismuh.ac.id/index.php/jpf

DOI: 10.26618/jpf.v9i1.4386

\section{A Contextual Semi-Assisted Project-Based Learning on Ocean Wave Energy: Pre-service Physics Teachers' Perceptions}

\author{
Muhammad Satriawan $^{1)^{*}}$, Liliasari ${ }^{2)}$, Wawan Setiawan ${ }^{3)}$, Ade Gafar Abdullah ${ }^{4}$, \\ Rosmiati $^{5}$ \\ ${ }^{1)}$ Program Studi Pendidikan Fisika, STKIP Bima, Bima, 84119, Indonesia. \\ ${ }^{2)}$ Program Studi Pendidikan IPA, Pascasarjana Universitas Pendidikan Indonesia, Bandung, 40154, Indonesia. \\ ${ }^{3)}$ Program Studi Ilmu Komputer, Universitas Pendidikan Indonesia, Bandung, 40154, Indonesia. \\ 4)Program Studi Pendidikan Teknik Elektro, Universitas Pendidikan Indonesia, Bandung, 40154, Indonesia.
}

*Corresponding author: satriawan.stkipbima@gmail.com

Received: November 26, 2020; Accepted: December 17, 2021; Published: January 29, 2021

\begin{abstract}
The lack of technological innovation in the utilization of ocean wave energy as a renewable energy source is caused by a lack of public knowledge about this matter. Therefore, it needs to be introduced early, especially to pre-service teachers through innovative and fun learning. The aim of this study was to identify the responses of pre-service physics teachers about the learning program to introduce the concept of utilizing ocean wave energy. The research subjects were 31 sixth semester students who are taking environmental physics lectures in the physics education study program at one of the teachers' university in West Nusa Tenggara Province for the 2019/2020 academic year. The sample was taken by using purposive sampling technique. Data collection was carried out by means of observation, interview, and questionnaire techniques. All data collected were then analyzed simultaneously descriptively. The findings of this study showed that almost $90 \%$ pre-service physics teacher students agreed that the learning program had a positive impact on increasing interest, motivation, critical thinking skills, and creative thinking skills, and made them easier to solve problems and grow solid cooperation. Therefore, it can be concluded that preservice physics teacher students agree to the use of semi-assisted project-based learning programs with contextual problems.
\end{abstract}

Keywords: Contextual problems, Ocean wave energy, Pre-service teacher perceptions, Semi assisted project based learning

(C) 2021 Physics Education Department, Universitas Muhammadiyah Makassar, Indonesia.

\section{INTRODUCTION}

Electrical energy is one of the most basic human needs that must be met. The increasing demand for electrical energy as a result of population growth is not linear with the availability of electrical energy supply in Indonesia. This has resulted in a national energy crisis because the availability of fossil fuels, which are used as the main source of electricity production, is running low 
(Rafique \& Rehman, 2017; Brockway et al., 2019; Phillis et al., 2020). This condition forces the government to find alternative energy sources such as new and renewable energy sources. In addition, the global commitment to reducing greenhouse gas emissions encourages the Government to continuously increase the role of new and renewable energy as part of maintaining energy security and independence. The role of renewable energy will be increasingly essential in the coming years in line with the increasing attention to energy security and issues related to the issue of global warming and climate change caused by high carbon dioxide $(\mathrm{CO} 2)$ emissions due to the use of fossil energy sources (Sasana \& Putri, 2018; Rehman et al., 2019; Sharvini et al., 2018). Therefore, the exploration of renewable energy is currently the focus of the government to anticipate the national energy crisis and minimize the impact of conventional energy use on the environment.

Indonesia has a very abundant potential source of renewable energy. Based on data released by the Directorate General of EBTKE (2013), the total potential of renewable energy used for electricity generation including hydro, geothermal, bioenergy, wind, solar and marine energy is $442 \mathrm{GW}$, while in 2019 the total power generation capacity (fossil and nonfossil) which is $64.5 \mathrm{GW}$. This shows that if renewable energy sources are utilized optimally, the national energy needs can be fulfilled and there will even be an energy surplus. However, in reality, the renewable energy sources available in Indonesian Nature have not been fully utilized. One example of an untapped renewable energy source in Indonesia is the technology of utilizing ocean waves to generate electricity even though the availability of ocean wave energy in Indonesia is very abundant, reaching 40 to $70 \mathrm{~kW} /$ meter (Zikra, 2017). Many factors become the obstacles why ocean wave energy has not been utilized as a renewable energy source in Indonesia, one of which is the lack of competent human resources in this field. In Indonesia, scientists rarely research and develop the use of ocean waves as a renewable energy source (Zikra, 2017). This is due to the low interest of students who take the major in this field, so that until now very few human resources have knowledge and competence in this field. This study in low innovation in technology development in the field of ocean wave energy utilization (Huynh et al., 2016).

The education system in Indonesia that does not introduce material about renewable energy comprehensively in schools has resulted in students not being interested in continuing their studies and even not interested in a career in renewable energy. Therefore, it really needs to be introduced early to the community, especially high school students about the scope of renewable energy so that they are interested in studying and having a career in the field of renewable energy (Huynh et al., 2016). This is where 
the role of a teacher is to make students interested and understand the concept of renewable energy comprehensively despite the lack of facilities available in schools. And even not only instilling the concept of renewable energy but equipping students with various important skills.

One thing that can be done is by using a contextual project-based learning that collaborate classroom and outside learning by utilizing nature, where the potential sources of renewable energy as a laboratory are available.

An example is making the beach a laboratory to introduce the concept of utilizing ocean wave energy as a renewable energy source. In order that the students can easily understand the material, a media or teaching aid is needed, such as a converter of ocean wave energy which is used to make it easier to communicate how the process of utilizing ocean wave energy to generate electricity. Contextual learning conditions like this should be applied more in the world of education than learning that is just face-to-face in class. Before this lecture program is used as an effective strategy in teaching and instilling competences related to the use of ocean waves as a renewable energy source, it is necessary to know how students respond to the program. Therefore, the aim of this study was to identify the responses of pre-service physics teachers about the learning program to introduce the concept of utilizing ocean wave energy.

\section{THEORETICAL BASIS}

\section{A. Contextual Teaching Learning Approach}

Contextual teaching-learning (CTL) is a holistic educational process and aims to motivate students to understand the meaning of the subject matter they are learning by linking the material to the context of their daily life (personal, social, and cultural context) so that students have knowledge or skills that can be flexibly applied (transferred) from one problem or context to another problem or context. CTL is also a learning concept that helps teachers relate the material they teach to real-world situations and encourages students to make connections between the material they teach and its application in their lives as family members and society (Aliyyah, 2020; Lotulung et al., 2018).

The principle of CTL is a learning concept that helps teachers link the material they teach with the real-world situation of students and encourages students to make connections between their knowledge and its application in their daily lives, which in effect involves seven main components of effective learning, namely: (1) Constructivism; learning by referring to CTL refers to constructivism, where students build their own understanding from new experiences based on initial knowledge (Sarita, 2017; Sharma \& Bansal, 2017). Learning must be packaged into a process of "constructing" not receiving knowledge. (2) Inquiry; In the pursuit of CTL, students carry out investigations, in learning 
Students learn to use critical thinking skills and a transfer process occurs from observation to understanding (Ernst et al., 2017). (3) Questioning; in the pursuit of asking questions carried out by both teachers and students (Halim \& Mazlina, 2018). Questions from the teacher are teacher activities to encourage, guide, and assess the thinking skills of students, while for students asking questions is an important part of inquiry-based learning. (4) Learning community; In CTL learning, a learning community should be created, namely the existence of a group of students who are engaged in learning activities, this refers to the principle that working with others is better than learning alone so that in the learning community there is an exchange of experiences or sharing of ideas. (5) Modeling; modeling is the process of showing an example so that other people think, work, and learn. In teaching students to do what the teacher wants students to do by first being given an example. (6) Reflection; At the end of the lesson students are invited to reflect, namely how to think about what we have learned; jotting down what you've learned, or keeping journals, artwork, group discussions. (7) Authentic assessment; assessment is carried out in various aspects, for example covering knowledge, skills, products (performance), as well as assessing relevant and contextual tasks.

\section{B. Semi Assisted Project-Based Learning}

A project is meaningful if it meets two criteria, namely (1) students must consider the work meaningful personally and as an important task they want to do well, (2) a meaningful project that fulfills educational objectives where project-based learning is well designed and well implemented. Larmer et al (2013) explains that in order for a project to be more meaningful, several things must be paid attention to, namely:

\section{Need to know}

Many students perceive school work as meaningless because they do not feel the need to know what is being taught to them. They are not motivated by the educator's suggestion that they must learn something because they will need it later, for the next education, or simply because of the exam material. With an interesting student project, the reasons for studying relevant material become clear that students need to know this to meet the challenges they have received (Amran et al., 2019).

\section{Driving question}

Good guiding questions are questions that capture the essence of the project in a clear and engaging language, which gives learners a sense of purpose and challenge. The questions should be provocative, open, complex, and related to the heart of what you want the student to learn. A project without driving questions is like an essay without a thesis. Without a thesis statement, the reader may be able to choose the main point the writer wants to make but with a thesis statement, the main point is unmistakable. Without guiding 
questions, students may not understand why they are doing the project. They know that the series of activities assigned to them have a relationship with a time period, place, or concept.

\section{Student voice and choice}

The more voices and choices from students are, the more meaningful and better the project will be. However, educators must design projects based on the choices of learners according to their own style. Students can choose what topics will be studied in the guiding questions or choose how to design, create, and present products. As a middle ground, educators might limit options to prevent learners from becoming overwhelmed with choices so that students can decide what products they will make, what resources they will use, and how they will structure their time. Learners can even select project topics and guiding questions themselves.

\section{21 st century skills}

A project should provide learners with the opportunity to build 21 st-century skills such as collaboration, communication, critical thinking, creativity, and the use of technology that will serve them well in the workplace and in life. These authentic skills meet the second criterion for meaningful work. An educator in a project-based learning environment explicitly teaches and assesses these skills and often provides learners with opportunities to assess themselves.

\section{Inquiry and innovation}

Learners find project work more meaningful if they do a real investigation, which doesn't mean finding information in books or websites and pasting it on posters. In the real-life inquiry, learners follow a trail that starts with their own questions, leads to resource searches and finding answers, and often ultimately leads to generating new questions, testing ideas, and drawing their own conclusions. With real questions comes an innovative new answer to a guiding question, a new product, or an individually tailored solution to a problem. Educators do not ask students only to reproduce information provided by Educators or textbooks in a better format. To guide students in real inquiry, educators must direct students to a list of questions that they create themselves.

\section{Feedback and revisions}

Formalizing processes for feedback and revision during the project makes learning meaningful because it emphasizes that creating high-quality products is an important goal of the effort. Students need to learn that most people's first efforts do not produce highquality products so revisions need to be made in order to produce a better product. In addition to providing direct feedback, educators must train students in using rubrics or other criteria to assess and critique their own work. Educators can involve experts to provide feedback, which is very meaningful to students. 


\section{Products presented to the public}

Schoolwork will be more meaningful if it is not done only for educators or exams. When students present their work to a real audience, they care more about the quality. Again, "the more, the better" when it comes to authenticity. Learners may imitate the types of tasks performed by professionals but even better, they can create tangible products that people use outside of school.

In this study, the BIE framework projectbased learning model adopted to develop critical thinking and creative thinking skills (Larmer et al., 2013). The project-based learning was modified by adding semiassistance during the learning process. The type of assistance provided is in the form of questions that direct students to solve the problems faced and assistance in the form of support facilities for project works so that the project is actually done by students and the processing time becomes more efficient.

\section{Ocean Wave Energy Utilization}

Wave energy or ocean wave energy is the energy generated from the movement of ocean waves towards land and vice versa. Basically, the movement of the sea that produces ocean waves occurs due to the impulse of wind movement. The wind arises due to a difference in pressure at 2 points which is caused by a different response of heating to the air by the sun at the two points (Shamsaddini \& Leman, 2016). Ocean waves can ideally be viewed as waves having a maximum peak height and a minimum valley. At certain intervals, the height of the crest reached by a series of ocean waves is different, even the height of this peak is different for the same location when measured on different days. However, statistically significant heights of sea waves can be determined at a certain location (Assis et al., 2014; Wang et al., 2016).

If the time required for a sea wave to occur is calculated from the data on the number of ocean waves observed at a certain interval, then the potential energy of ocean waves at that location can be determined. The potential of ocean wave energy at one point of observation in units of $\mathrm{kW}$ per meter is directly proportional to half of the square of the significant height times the time it takes for an ocean wave to occur. Based on this calculation, various potential energy from ocean waves can be predicted in various places in the world (Sarkar et al., 2016; Chiu et al., 2017). Basically, the working principle of technology that converts ocean wave energy into electrical energy is to accumulate ocean wave energy to turn a generator turbine (Waves, 2017; Bourgault \& Galbraith, 2016; Bozzi et al., 2013). Therefore it is very important to choose a location that allows topographical accumulation of energy.

An alternative to ocean wave power generation technology that is more developed is the oscillating water column technique (Song \& Park, 2016; Sheng \& Lewis, 2016). The process of generating electric power with this technology goes through 2 stages of the process. The incoming sea waves 
press the air in the water column which is then forwarded to the column or closed space connected to the generator turbine. This pressure drives the power generator turbine. Conversely, ocean waves leaving the water column are followed by air movement in an enclosed space that drives a power generator turbine (Song \& Park, 2016).

The advantages of the wave energy conversion technique into electricity are: (1) wave energy is an energy that can be obtained every day, never runs out; (2) does not cause pollution because there is no waste; (3) easy to convert electrical energy from mechanical energy to waves; (4) there is no need to design structures with excessive strength such as wind turbines which are designed to take into account the presence of hurricanes because physical conditions at certain depths tend to be calm and predictable.

\section{METHODS}

The research was conducted in a physics education study program at one of the Teacher's University in West Nusa Tenggara Province, semester of the 2019/2020 academic year. The population of this research was preservice physics teachers of physics education study program who have followed environmental physics lecture. The research samples were 31 sixth semester pre-service physics teachers. The sample was taken by using the purposive sampling technique. Data collection refers to the instruments used, namely the observation, interviews, and student questionnaires. All data collected were then analyzed simultaneously by using descriptive analysis. Furthermore, the results of data analysis are used to answer research problems.

Perception data of pre-service physics teachers that have been collected using a questionnaire is used to describe the responses of pre-service physics teachers to this program's ability to increase their motivation, reduce cognitive load, foster interest in learning about the use of ocean wave energy, provide critical thinking skills, provide creative thinking skills, provide clarity in assignments, assist in solving problems and foster student collaboration in their groups during the lecture. Responses were classified into several response categories, namely strongly agree (SA), agree (A), disagree (D), and strongly disagree (SD) (Maeda, 2015). The response data is analyzed with the percentage of respondents' response (PRR) in each category using equation 1 as follows:

$$
P R R(\%)=\frac{N R}{T N R} \times 100 \% \text { (1) }
$$

Where NR is the number of respondents to a response, and TNR is the total number of respondents. Meanwhile, the observation and interview data were analyzed descriptively. Both of these data were used to back up the questionnaire data. 


\section{RESULTS AND DISCUSSION}

A contextual semi-assisted project-based learning in this study is a learning program in which pre-service physics teachers are directed to learn through contextual project work on the ocean wave energy utilization as a renewable energy source. As for the implementation of lectures, only $30 \%$ is done in the classroom and the rest is done in workshops and on the beach. Activities in class are only at the beginning of lectures and project work is carried out in a workshop and product testing of the project results is carried out at sea or on the beach. In this learning program, preservice physics teachers are assisted by a prototype of ocean wave energy as an initial model. And with this prototype pre-service physics teachers are motivated to develop an ocean wave energy converter that is different from the prototype shown. The student responses related to the lecture are as shown in the data presented in table 1 .

Table 1. Pre-service physics teacher's responses to the learning program

\begin{tabular}{|c|c|c|c|c|c|c|c|c|c|}
\hline \multirow{3}{*}{ No. } & \multirow{3}{*}{ Responded aspects } & \multicolumn{8}{|c|}{ \% Amount of pre-service physics teachers responses } \\
\hline & & \multicolumn{4}{|c|}{ Positive statements } & \multicolumn{4}{|c|}{ Negative statements } \\
\hline & & SA & A & D & SD & SA & A & D & SD \\
\hline 1 & Learning motivation & 29.03 & 64.52 & 4.84 & 1.61 & 3.23 & 9.68 & 67.74 & 19.35 \\
\hline 2 & $\begin{array}{l}\text { Use of teaching aids (ocean } \\
\text { wave energy converter } \\
\text { prototype) }\end{array}$ & 30.65 & 66.13 & 3.23 & 0.00 & 0.00 & 3.23 & 41.94 & 54.84 \\
\hline 3 & $\begin{array}{l}\text { Interest in studying the } \\
\text { material of ocean wave } \\
\text { energy and its utilization }\end{array}$ & 54.84 & 40.32 & 4.84 & 0.00 & 3.23 & 3.23 & 25.81 & 67.74 \\
\hline 4 & $\begin{array}{l}\text { Critical thinking skills } \\
\text { equipment }\end{array}$ & 38.71 & 56.45 & 4.84 & 0.00 & 3.23 & 3.23 & 61.29 & 32.26 \\
\hline 5 & $\begin{array}{l}\text { Creative thinking skills } \\
\text { equipment }\end{array}$ & 35.48 & 59.68 & 3.23 & 1.61 & 0.00 & 6.45 & 45.16 & 48.39 \\
\hline 6 & Clarity in assignment & 25.81 & 67.74 & 3.23 & 3.23 & 4.84 & 9.68 & 61.29 & 24.19 \\
\hline 7 & Problem solving & 27.42 & 66.13 & 4.84 & 1.61 & 3.23 & 3.23 & 61.29 & 32.26 \\
\hline 8 & Work in groups & 45.16 & 53.23 & 1.61 & 0.00 & 0.00 & 3.23 & 61.29 & 35.48 \\
\hline
\end{tabular}

The success of a learning program is of course not only in terms of an increase in student skills or learning outcomes. However, there are other aspects that need to be considered, namely what the pre-service physics teachers' response or perception to the learning process (Loh, 2016; Noreen et al., 2018). What's more, the different characteristics of pre-service physics teachers certainly cause different responses. Likewise, the learning program in environmental physics lectures gets different student responses and responses as shown in table 1 . Based on table 1 , overall all aspects of the statement, both positive statements and negative statements, 
are responded to positively by pre-service physics teachers.

In the aspect of the statement "enthusiasm in participating in learning" in the positive statement, there were $64.52 \%$ who responded "agree" and $29.03 \%$ of the number of preservice physics teachers who strongly agreed. Whereas in the negative statement, there were $67.74 \%$ who disagreed and $19.35 \%$ who strongly disagreed. This shows that learning about wave energy using this learning program can improve the students' motivation. Even though at the beginning of the lesson the preservice physics teachers looked indifferent, but along with the learning situation was changing from the classroom to the beach and so on in the workshop, the pre-service physics teachers' initial impression changed. This is in line with what was stated by Utaminingsih (2015) and Al Bahij et al., (2018) that the learning environment affects students' interest and motivation in which learning outside the classroom such as in the natural environment can make learning fun.

In the aspect of the statement "the use of teaching aids in the form of a wave energy converter" received a response "agree" of $66.13 \%$ and "strongly agree" of $30.65 \%$ on a positive statement. On the negative statement, the number of pre-service physics teachers giving responses "strongly disagree" of $54.84 \%$ and "disagree of $41.94 \%$. This means that the use of teaching aids in the form of a sea wave energy converter in the learning program makes a positive contribution to the learning process. This is in line with what is stated by Haryadi (2019) and Muhomi \& Mbise (2017) that the use of teaching aids can attract students' attention so as to increase student interest in learning the concepts to be conveyed.

What is interesting is when the statement on the aspect of "interest in studying the material of ocean wave energy and its utilization". In the positive statement, there were $54.84 \%$ who stated "strongly agree" and $40.32 \%$ of the total pre-service physics teachers who stated "agree" while in the negative statement there was $67.74 \%$ who stated "strongly disagree" and $24.81 \%$ of preservice physics teachers who declared "disagree". This means that the existence of this learning program helped the pre-service physics teachers to have very high motivation and interest in studying the material of ocean wave energy and its use as a renewable energy source.

Likewise, with student responses to aspects of the ability of the learning program in providing pre-service physics teachers with critical thinking skills and creative thinking skills. The responses given by pre-service physics teachers were also very good, in which the dominant positive statements the preservice physics teachers agreed that the learning program at every stage equips them with critical thinking skills and creative thinking skills. Likewise, with the negative statement where the dominant aspect was critical thinking skills, pre-service physics 
teachers did not agree that the learning program did not contribute to improving preservice physics teachers' critical thinking skills. While negative statements for the creative thinking aspect, the dominant student gave a very disapproving response that the learning program did not equip creative thinking skills at every stage of learning. From the student's responses, it can be concluded that the pre-service physics teachers agreed that during the environmental physics lecture, both critical thinking skills and creative thinking skills were always provided at each learning stage. This is in accordance with the results of research Kartika et al. (2019) and Rachmawati et al. (2018) that project-based learning can improve students' critical thinking skills and creative thinking skills simultaneously.

Other aspects that were responded to by pre-service physics teachers were clarity in assigning assignments, solving problems, and working in groups. The responses given by pre-service physics teachers to these three aspects both in positive statements and negative statements have similarities, namely getting good responses from pre-service physics teachers. In a positive statement, the dominant pre-service physics teachers agreed that the learning program had a clear assignment. In addition, the learning program is also able to guide pre-service physics teachers in finding solutions to problems through projects undertaken by pre-service physics teachers, and each group member always works together. Likewise, with negative statements, the dominant pre-service physics teachers did not agree that the learning program had unclear assignments and confused pre-service physics teachers so that they had difficulty finding solutions to problems. The student's response is in line with the research results of Vogler et al. (2018) which reveals that project activities can foster solid teamwork and Jalinus \& Nabawi (2017) revealed that through project activities students find it easier to solve the problems they face because the problems they face are very clear.

\section{CONCLUSION AND SUGGESTION}

Based on the results of the research above, it can be concluded that the semi-assistance project-based learning program with contextual problem received a positive response. The applied learning program can increase the students' motivation, reduce cognitive load, foster interest in learning about the use of ocean wave energy, equip critical thinking skills, provide creative thinking skills, provide clarity in assignments, assist in solving problems, and foster students' collaboration in groups. As the recommendations for further researcher, there is a need to further identify the responses related to the constraints faced by pre-service physics teachers while working on a project so that it can be used as a reference for improving contextual project-based learning programs with semi-assistance. 


\section{ACKNOWLEDGMENTS}

The Authors would like to thanks to RISTEK DIKTI has founded all research activities and has given doctoral scholarships. And the second, the authors also like to everyone who have participated in this research and the staff who has given the chance to conduct this research.

\section{REFERENCES}

Amran, A., Perkasa, M., Jasin, I., Satriawan, M., \& Irwansyah, M. (2019). Model pembelajaran berbasis nilai pendidikan karakter untuk generasi indonesia abad 21. Lentera Pendidikan: Jurnal Ilmu Tarbiyah dan Keguruan, 22(2), 233$242 . \quad$ http://journal.uinalauddin.ac.id/index.php/lentera_pendi dikan/article/viewFile/6296/7801

Al Bahij, A., Santi, A. U. P., \& Prastiwi, D. A. (2018, July). Pemanfaatan lingkungan alam sekitar sebagai media ajar di Sekolah Dasar Negeri 2 Sirah Pulo Padang. In Prosiding Seminar Nasional Pendidikan 1(1). https://jurnal.umj.ac.id/index.php/SNP /article/view/2762/2223

Aliyyah, R. R., Ayuntina, D. R., Herawati, E. S. B., \& Suhardi, M. (2020). Using of contextual teaching and learning models to improve students natural science learning outcomes. Indonesian Journal of Applied Research 1(2), 6579.

https://doi.org/10.30997/ijar.v1i2.50

Assis, E. A., Beluco, A., \& De Almeida, L. E. B. (2014). On the wave energy potensial along the southern coast of Brazil. International Journal of Energy and Environment 5(1), 59-66. http://www.ijee.ieefoundation.org/vol 5/issue1/IJEE_06_v5n1.pdf

Bourgault, D., Galbraith, P. S., \& Chavanne, C. (2016). Generation of internal solitary waves by frontally forced intrusions in geophysical flows. Nature communications $7(1), \quad 1-9$. https://doi.org/10.1038/ncomms13606

Bozzi, S., Miquel, A. M., Antonini, A., Passoni, G., \& Archetti, R. (2013). Modeling of a point absorber for energy conversion in Italian seas. Energies 6(6), 3033-3051. https://doi.org/10.3390/en6063033

Chiu, S., Wang, J., Wang, S., \& Chao, S., D. (2017). Enhancement of sea wave potential energy with under-sea periodic structures: A simulation and laboratory study. Applied Sciences 7(8), 782-797.

https://doi.org/10.3390/app7080782

Larmer, J., Mergendoller, J., \& Boss, S. (2013). PBL for 21st century success. Buck Institute for Education. Novato: California.

Brockway, P. E., Owen, A., Brand-Correa, L. I., \& Hardt, L. (2019). Estimation of global final-stage energy-return-oninvestment for fossil fuels with comparison to renewable energy sources. Nature Energy, 4(7), 612-621. https://doi.org/10.1038/s41560-0190425-z

Ditjen EBTKE. (2013). Statistik EBTKE 2013. Direktorat Jenderal Energi Baru, Terbarukan, dan Konservasi Energi, Kementerian Energi dan Sumber Daya Mineral. Jakarta. http://ebtke.esdm.go.id/post/2014/07/0 1/627/statistik.2013

Ernst, D. C., Hodge, A., \& Yoshinobu, S. (2017). What is inquiry-based learning. Notices of the AMS, 64(6), 570-574.

https://www.ams.org/journals/notices/ 201706/rnoti-p570.pdf

Halim, A., \& Mazlina, H. (2018, September). Questioning skill of science teacher from the students perscpective in senior high school. Journal of Physics Conference Series 1088 (1), 012109. https://doi.org/10.1088/1742$\underline{6596 / 1088 / 1 / 012109}$

Haryadi, R., Vita, M., Utami, I. S., Ihsanudin, I., Setiani, Y., \& Suherman, A. (2019). Briquettes production as teaching aids physics for improving science process 
skills. Journal of Physics Conference

Series, 1157(3), 032006

https://doi.org/10.1088/17426596/1157/3/032006

Huynh, T., Hou, G., \& Wang, J. (2016). Communicating wave energy: An active learning experience for students. American Journal of Engineering Education 7(1), 37-46. https://files.eric.ed.gov/fulltext/EJ110 3434.pdf

Jalinus, N., \& Nabawi, R. A. (2017). Implementation of the PjBL model to enhance problem solving skill and skill competency of community college student. Jurnal Pendidikan Vokasi 7(3), 304-311. https://journal.uny.ac.id/index.php/jpv/ article/view/14286

Kartika, S., Saepuzaman, D., Rusnayati, H., Karim, S., \& Feranie, S., A. (2019). The influence of scientific creativity and critical worksheet (SCCW) on project based learning to increase cognitive ability, scientific creative skills and scientific critical skills senior high school students on sound wave problem. Journal of Physics: Conference Series, 1280(5). https://doi.org/10.1088/17426596/1280/5/052002

Loh, C., Wong, D. H., Quazi, A., \& Kingshott, R., P. (2016). Re-examining students' perception of e-learning: an Australian perspective. International Journal of Educational Management, $30(1)$, 1-20.

https://doi.org/10.1108/IJEM-082014-0114

Lotulung, C. F., Ibrahim, N., \& Tumurang, H. (2018). Effectiveness of learning method contextual teaching learning (CTL) for increasing learning outcomes of entrepreneurship education. Turkish Online Journal of Educational TechnologyTOJET, 17(3), 37-46.

https://files.eric.ed.gov/fulltext/EJ118 4198.pdf

Maeda, H. (2015). Response option configuration of online administered Likert scales. International Journal of
Social Research Methodology, 18(1), 15-26.

Muhomi, H., \& Mbise, M. (2017). Development of multimedia teaching aids for selected physics sub-topics from the topic of simple machine in tanzanian secondary schools. Huria: Journal of the Open University of Tanzania, 24(2), 97-109. https://www.ajol.info/index.php/huria/ article/view/168090

Noreen, K., Khan, K. A., \& Nehra, R. A. (2018). Students' perception of learning environment using dundee ready education environment measure (dreem) inventory. Pakistan Journal of Public Health, 8(2), 112-116. https://doi.org/10.32413/pjph.v8i2.154

Phillis, A., Grigoroudis, E., \& Kouikoglou, V. S. (2020). Assessing national energy sustainability using multiple criteria decision analysis. International Journal of Sustainable Development \& World Ecology, 1-18. https://doi.org/10.1080/13504509.202 0.1780646

Rafique, M. M., \& Rehman, S. (2017). National energy scenario of PakistanCurrent status, future alternatives, and institutional infrastructure: An overview. Renewable and Sustainable Energy Reviews, 69, 156-167. https://doi.org/10.1016/j.rser.2016.11. 057

Rachmawati, I., Feranie, S., Sinaga, P., \& Saepuzaman, D. (2018). Penerapan pembelajaran berbasis proyek untuk meningkatkan keterampilan berpikir kreatif ilmiah dan berpikir kritis ilmiah siswa SMA pada materi kesetimbangan benda tegar. Wahana Pendidikan Fisika, 3(2), 25-30. https://ejournal.upi.edu/index.php/WP F/article/view/13725

Rehman, A., Rauf, A., Ahmad, M., Chandio, A. A., \& Deyuan, Z. (2019). The effect of carbon dioxide emission and the consumption of electrical energy, fossil fuel energy, and renewable energy, on economic performance: evidence from Pakistan. Environmental Science and 
Pollution Research, 26(21), 2176021773. https://doi.org/10.1007/s11356019-05550-y

Sarita, P. (2017). Constructivism: A new paradigm in teaching and learning. International Journal of Academic Research and Development, 2(4), 183-186. http://www.academicjournal.in/archiv es/2017/vol2/issue4/2-4-111

Sarkar, D., Contal, E., Vayatis, N., \& Dias, F. (2016). Prediction and optimization of wave energy converter arrays using a machine learning approach, Renewable Energy, 97, 504-517. https://doi.org/10.1016/j.renene.2016. $\underline{05.083}$

Sasana, H., \& Putri, A. E. (2018). The increase of energy consumption and carbon dioxide $(\mathrm{CO} 2)$ emission in Indonesia. In E3S Web of Conferences, 31,01008. EDP Sciences. https://doi.org/10.1051/e3sconf/20183 101008

Shamsaddini, E. and Leman, Z. (2016). Renewable energy sources and analyzing the wind turbine performance. A Review, 780-802. https://doi.org/10.5902/2179460X21523

Sharma, M. S., \& Bansal, D. (2017). Constructivism as paradigm for teaching and learning. International Journal of Physical Education, Sports and Health, 4(5), 209-212. https://www.kheljournal.com/archives/ 2017/vol4issue5/PartD/4-5-41-636.pdf

Sharvini, S. R., Noor, Z. Z., Chong, C. S., Stringer, L. C., \& Yusuf, R. O. (2018). Energy consumption trends and their linkages with renewable energy policies in east and southeast Asian countries: Challenges and opportunities. Sustainable

Environment Research, 28(6), 257266.

https://doi.org/10.1016/j.serj.2018.08. $\underline{006}$

Sheng, W. \& Lewis, T. (2016). Energy conversion: A comparison of fix- and self-referenced. Energies, 9(12), 1-19. https://doi.org/10.3390/en9121056
Sjökvist, L. \& Göteman, M. (2017). Peak forces on wave energy linear generators in tsunami and extreme waves, 10(9), 1323-1342. https://doi.org/10.3390/en10091323

Song, S., \& Park, J. (2016). Control strategy of an impulse turbine for an oscillating water column-wave energy converter in time-domain using lyapunov stability method, Applied Sciences, $6(10)$, $1-23$ https://doi.org/10.3390/app6100281

Utaminingsih, R. (2015). Pemanfaatan lingkungan sebagai laboratorium alam pada pembelajaran IPA SD, Trihayu, 2(1), 215-220. https://media.neliti.com/media/publica tions/259106-pemanfaatanlingkungan-sebagai-laborator697b485a.pdf

Vogler, J. S., Thompson, P., Davis, D. W., Mayfield, B. E., Finley, P. M., \& Yasseri, D. (2018). The hard work of soft skills: augmenting the projectbased learning experience with interdisciplinary

teamwork. Instructional Science,46(3), 457-488.

https://doi.org/10.1007/s11251-0179438-9

Wang, L., Engström, J., Leijon, M., \& Isberg, J. (2016). Coordinated control of wave energy converters subject to motion constraints. Energies, 9(6), 475-489. https://doi.org/10.3390/en9060475

Zikra, M. (2017). Preliminary assessment of wave energy potential around indonesia sea. Applied Mechanics and Materials $\quad 862, \quad 55-60$. https://doi.org/10.4028/www.scientific .net/AMM.862.55 